\title{
Distribution and Eruptive Mechanism of Maars in the Kamchatka Peninsula
}

\author{
A. B. Belousov \\ Presented by Academician V.I. Kovalenko May 19, 2005
}

Received May 24, 2005

DOI: $10.1134 / \mathrm{S} 1028334 \mathrm{X} 06010077$

Maars are monogenic volcanic edifices of peculiar morphology with a wide circular crater surrounded by a low gentle rim of erupted pyroclastic material. Craters of maars are deeply incised into underlying rocks (frequently down to the aquifer), which explains their frequent partial or complete water infill. Owing to their morphological peculiarities, maars are easily identifiable in air photos.

Maars are widespread in many volcanic areas of the world, where they occur both within volcanic fields and on slopes of stratovolcanoes (craters of subsidiary eruptions). It is established that maars are formed during the highly explosive interaction between ascending magma and groundwaters. Therefore, their presence is indicative of the phreatomagmatic eruptive mechanism [11]. We present the first overview of maars of the Kamchatka Peninsula. The main purpose of this work is to estimate the role of the phreatomagmatic mechanism during eruptions of monogenic volcanoes of Kamchatka and to reveal factors controlling the geographical distribution of maar-forming eruptions.

Occurrence frequency and distribution of maars. In total, 14 maars with a crater diameter of $>600 \mathrm{~m}$ have been identified in Kamchatka using air photos and published materials [3-8] (table). It is difficult to identify smaller maars. We believe that their number does not exceed 20 . Thus, maars constitute less then $1 \%$ of the total number of monogenic volcanic edifices in the peninsula. Tuff cones and tuff rings that are composed of products of phreatomagmatic eruptions are even rarer. Other types of monogenic volcanoes dominated by cinder cones are related to eruptions characterized mainly by the magmatic mechanism of magma fragmentation [11]. Hence, eruptions with a prevalent phreatomagmatic eruption mechanism are rare in Kamchatka.

Institute of Marine Geology and Geophysics, Far East Division, Russian Academy of Sciences, ul. Nauki, Yuzhno-Sakhalinsk, 693022 Russia; e-mail:belousov@mail.ru
The geographic distribution of maars throughout the Kamchatka Peninsula is very irregular (Fig. 1), with their concentration being independent of the total number of monogenic edifices in particular areas. For example, the Klyuchevskaya group of volcanoes hosts numerous monogenic cinder cones, but maars are lacking here. They are also extremely scarce in the Sredinnyi Range (Kamchatka), where intense volcanism produced numerous isolated cinder cones, lava flows, and extrusive domes. Inasmuch as phreatomagmatic eruptions require water, in addition to magma, we attempted to estimate the influence of this factor on the localization of maar-forming eruptions in Kamchatka.

The concentration of maars on the peninsula as a whole gradually increases southward to reach a maximum at its southern end. Comparison of the map of distribution of Pleistocene-Holocene volcanics and the map of annual atmospheric precipitation revealed that maars are concentrated in volcanic areas with the most humid climate (precipitation exceeds $1200 \mathrm{~mm} / \mathrm{yr}$ ). Hence, maars are absent in some areas because of the water deficiency preventing phreatomagmatic eruptions.

Several large maars of Kamchatka, such as the Nachikinskii, Krokur, and Chasha, formed near natural reservoirs (the Bering Sea, Lake Kronotskoe, and Lake Tolmachevo, respectively). Migrating through the aquifer, waters of these reservoirs probably contributed to eruptions. The echo sounding of the Chasha Maar showed that the lake level abruptly rose by $18 \mathrm{~m}$ (maximal depth increased to $42 \mathrm{~m}$ ) several years ago, when the water level in the large Lake Tolmachevo located nearby was elevated by the same value as a result of dam construction. Thus, the two lakes are closely connected through the aquifer.

Most of the Kamchatka maars are located in lowlands, where groundwaters occur near the surface. If the eruptive fissure crosses the differentiated relief, maars are usually located at the hypsometrically lowest segment of the fissure, while its higher segments are occupied by cinder cones and lava flows. For example, the Lake Dal'nee Maar formed inside the Uzon Caldera 
Characteristics of maars in Kamchatka (from north to south)

\begin{tabular}{l|c|c|c}
\hline \multicolumn{1}{c|}{ Maar name } & Maar age, yr BP & Crater diameter, km & $\begin{array}{c}\text { Composition of juvenile } \\
\text { material }\end{array}$ \\
\hline Nachikinskii & 10000 & 1.6 & Basalt \\
Kenenin (Lake Blyudechko) & 1100 & 1.6 & The same \\
Krokur & 4300 & 1.3 & Basaltic andesite \\
Lake Dal'nee & 3300 & 1.2 & Basalt \\
Valentiny & $>10000$ & 0.8 & The same \\
Lake Sukhoe & $>10000$ & 2.0 & $"$ \\
Koldobishche & 1200 & 0.3 & Rhyolite \\
Lake Chasha (gr. 2) & 4600 & $1.2 ; 0.4$ & The same \\
Baranii Amfiteatr & 1500 & 1.4 & Basalt \\
Temnoe Mesto* (gr. 3) & 8000 & $0.7 ; 0.2 ; 0.2$ & Basalt (?) \\
Khetik* & $?$ & 0.3 & Rhyolitic dacite \\
Khodutkinskii I (gr. 2) & 2800 & $1.5 ; 0.4$ & $?$ \\
Khodutkinskii II (gr. 2) (Lake Chernoe) & $?$ & $0.8 ; 0.3$ & Basalt (?) \\
Krestovka* & $?$ & 0.8 & The same \\
Lake Krugloe & $9000(?)$ & 0.8 & Andesite \\
Il'inskii I* & $1901,$, & 0.8 & $?$ \\
Il'inskii II* & $?$ & 0.3 & $?$ \\
\hline
\end{tabular}

Note: Only maars confidently outlined by morphological and geological data are listed. Asterisk designates previously unknown maars (named by us after the closest rivers or volcanoes); (gr.) group of maars with indication of the number of craters. Rounded ages and compositions of juvenile material of maars are given after [3-8]. According to [3], the Lake Dal'nee Maar is 7700 yr old, but we consider it to be contemporaneous with the Duga cone (3300 yr [3]). The Baranii Amfiteatr and Khodutkinskii group I are described in [3] as craters of "subcaldera eruptions", but they represent maars based on morphology. In some works, the Tokareva Crater produced by the eruption in Lake Karymskoe in 1996 is attributed to maars. However, based on morphological features, we class it as a tuff ring $[2,10]$ and omit it from consideration.

depression, whereas the Duga cinder cone with lava flow was formed appeared at a continuation of the eruptive fissure on its high slope. Similar regularity is noted also for the Eifel maars [12]. Thus, maars form in areas where the water-rich aquifer is located sufficiently close to the surface (at a depth of tens to a few hundreds of meters). In the case of its deeper position, no explosive interaction between magma and water occurs, because the high lithohydrostatic pressure suppresses this process.

Morphology of maars. Maar craters in the Kamchatka Peninsula are up to $2 \mathrm{~km}$ across, with small craters $(<0.5 \mathrm{~km})$ being prevalent (Fig. 2). The maar size depends on the power and duration of the corresponding explosive eruption. Therefore, most of the maarforming eruptions in Kamchatka were relatively weak. Depths of maar craters are tens to hundreds of meters. However, their primary depths are unknown since they are partly filled with water and/or lacustrine deposits. Sometimes, the maars are filled with products of subsequent magmatic stages of eruptions.

Most of the Kamchatka maars represent isolated edifices, but one can also see closely spaced groups (for example, the Temnoe Mesto group of three maars) or chains (the Chasha group of a dry funnel and two merged maars occupied by a lake).

Certain morphological features of many Kamchatka maars, such as the presence of an intracrater cinder cone, extrusive dome, or lava flow, suggest that the terminal phase of their formation was marked by a transition from the phreatomagmatic eruptive mechanism to the magmatic one. This indicates that in many cases aquifers could not provide a sufficient water influx for the functioning of the phreatomagmatic mechanism of magma fragmentation throughout the entire eruption period.

Deposits. Most of the Kamchatka maars resulted from eruptions of mafic magmas, although there are also maars formed by acid (up to rhyolitic) varieties. The maximal thickness of pyroclastic deposits in maars amounts to several tens of meters. The deposits in the examined Krokur, Lake Dal'nee, and Chasha maars are, in general, uniform. They are represented by alternating layers of tephra and pyroclastic surges (each a few tens of centimeters thick). The deposit frequently encloses accretionary lapiili that testify to the conden- 


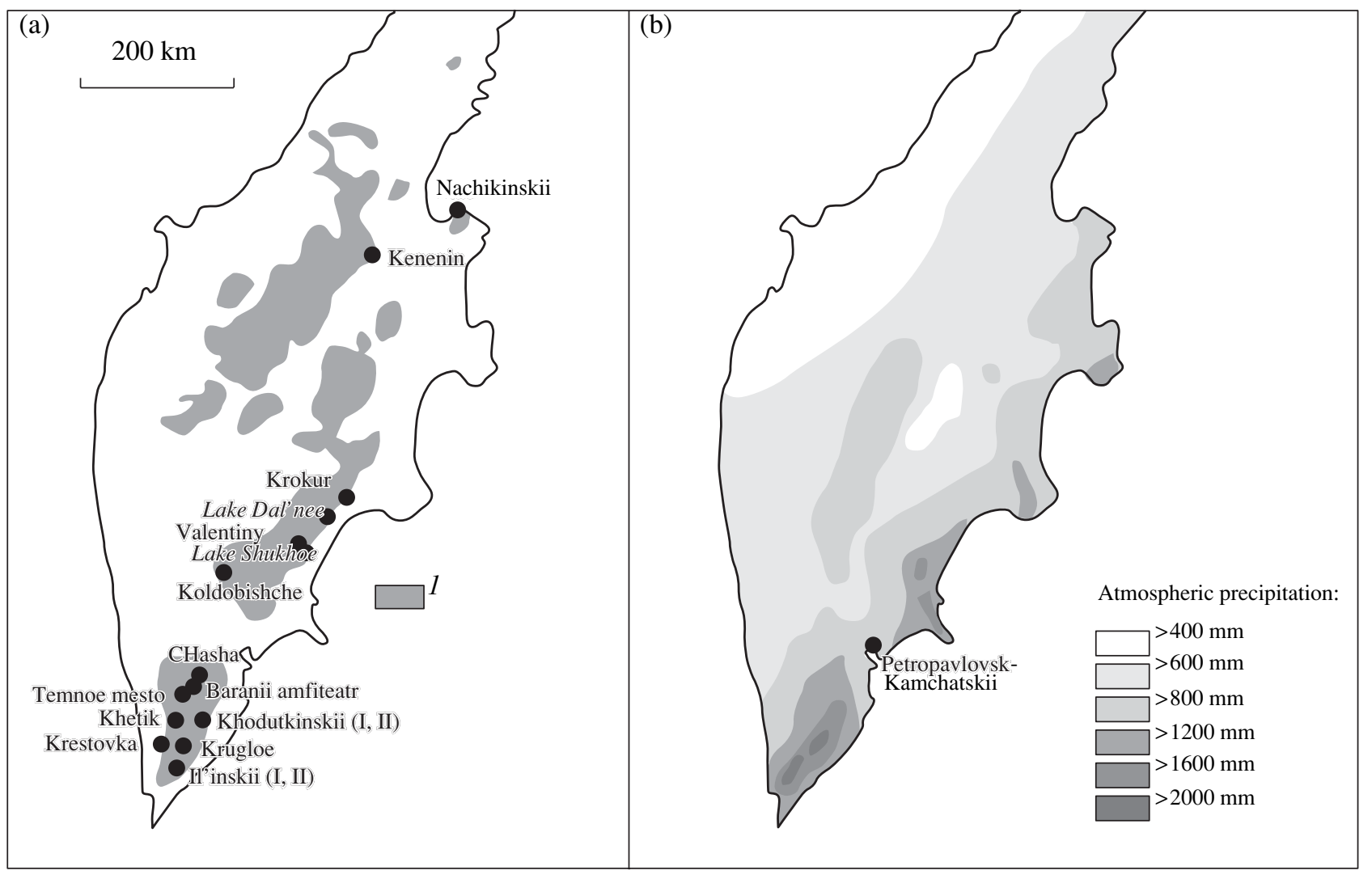

Fig. 1. Geographic distribution of maars (a) and amount of atmospheric precipitation (b) in the Kamchatka Peninsula. Most of the maar-forming eruptions took place in areas where volcanism occurs against the background of a wet climate. (1) Distribution of volcanics [9]; atmospheric precipitation [1].

sation of large volumes of water vapor in the eruptive cloud. Each maar resulted from a single eruption consisting of a series (from tens to hundreds) of separate successive explosions. This reflects a very unstable

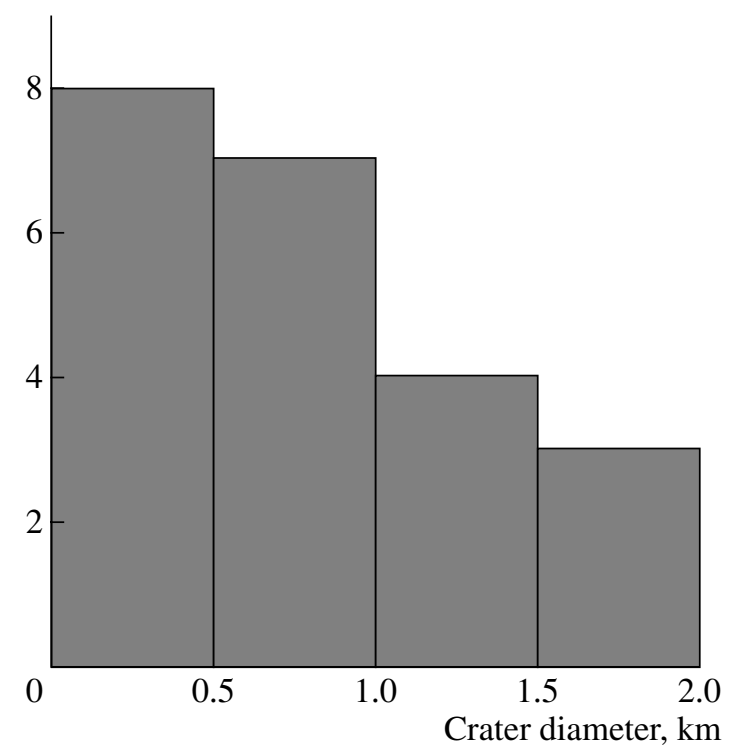

Fig. 2. Diameter of craters of the Kamchatka maars. pulsing character of the eruptive process in the course of the magma-water interaction.

The deposits are represented by mixture of fragments of juvenile (fresh magma) and resurgent material (crushed basement rocks related to excavation of the maar crater). Juvenile material from each eruption is characterized by a relatively low average vesicularity (large density of pyroclastic particles) and a wider polymodal distribution of vesicularity as compared with products of purely magmatic eruptions (Fig. 3). This suggests the quenching of magma by water at different stages of the release of volatiles (interrupted magma vesiculation) and indicates, along with the block morphology of most pyroclastic particles, the dominant phreatomagmatic mechanism responsible for the formation of Kamchatka maars. In some cases (for example, the Lake Dal'nee Maar), the upper part of the section is characterized by a sharp increase in the vesicularity of juvenile material (Fig. 3), which is explained by the cessation of water influx to the magmatic channel at the terminal stage of maar-forming eruptions and the transition from the phreatomagmatic mechanism of magma fragmentation to the magmatic one.

Age. Most of the maars in the Kamchatka Peninsula have Holocene age and only a limited number of them are attributed to the Late Pleistocene. Maars of pre- 
Lake Dal'nee

Amount of fragments, $\%$
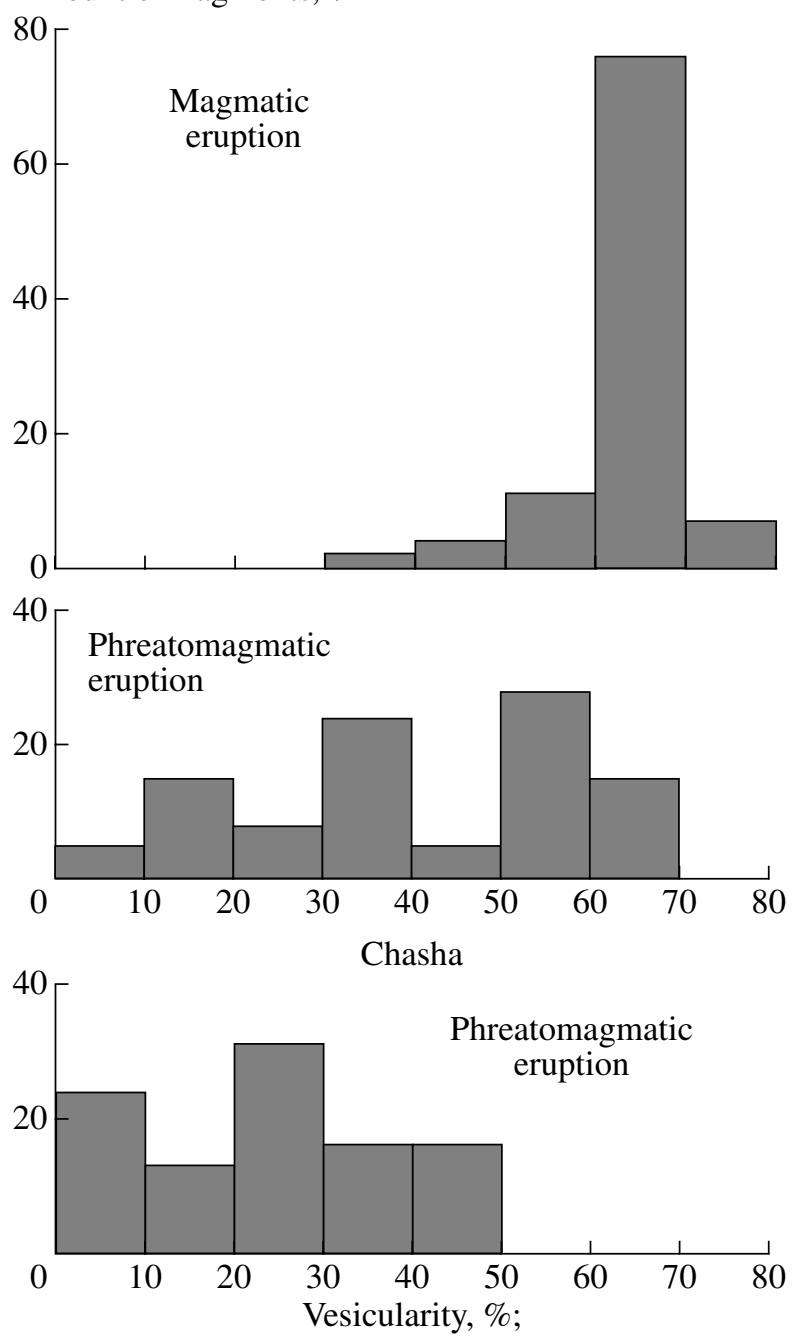

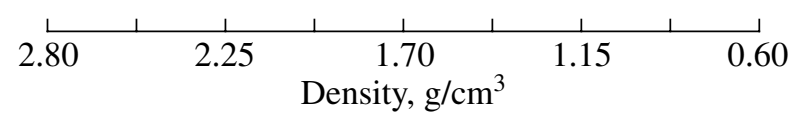

Fig. 3. Distribution of the density (vesicularity) of juvenile pyroclastic particles in the Chasha (rhyolites) and Lake Dal'nee (basaltic andesite) maars. For the Lake Dal'nee Maar, data characterizing the initial (phreatomagmatic) and terminal (magmatic) stages are given.
Holocene age are probably either buried by younger volcanogenic deposits or were destroyed by the last glaciation. The available data provide evidence that maars in this region formed at a relatively regular rate throughout the entire Holocene.

\section{ACKNOWLEDGMENTS}

This work was supported by the Russian Foundation for Basic Research and the CRDF grant.

\section{REFERENCES}

1. Atlas of the USSR (Moscow, 1984) [in Russian].

2. A. B. Belousov, M. G. Belousova, and Ya. D. Murav'ev, Dokl. Akad. Nauk 354, 648 (1997) [Dokl. Earth Sci. 355 653 (1997)].

3. O. A. Braitseva, I. V. Melekestsev, V. V. Ponomareva, et al., Vulkanol. Seismol., Nos. 4-5, 5 (1994).

4. O. V. Direksen and I. V. Melekestsev, Vulkanol. Seismol., No. 1, 3 (1999).

5. O. V. Direksen, V. V. Ponomareva, and L. D. Sulerzhitskii, Vulkanol. Seismol., No. 5, 3 (2002).

6. B. V. Ivanov, Eruption of Karymskii Volcano in 19621965 and Volcanoes of the Karymskii Group (Nauka, Moscow, 1970) [in Russian].

7. I. V. Melekestsev, O. A. Braitseva, L. I. Bazanova, et al., Vulkanol. Seismol., No. 2, 3 (1996).

8. M. M. Pevzner, in Abstracts of the 4th International Meeting on Processes in Subduction Zones of the Japan, Kuril-Kamchatka, and Aleutian Island Arcs (Petropavlovsk-Kamchatskii, 2004), pp. 72-74 [in Russian].

9. Active Volcanoes of Kamchatka, Ed. by S.A. Fedotov (Nauka, Moscow, 1991) [in Russian].

10. A. Belousov and M. Belousova, in Volcaniclastic Sedimentation in Lacustrine Settings (IAS, 2001), Spec. No. 30, pp. 35-60 [in Russian].

11. P. Fransis, Volcanoes: A Planetary Perspective (Clarendon Press, Oxford, 1993).

12. V. Lorenz, Bull. Volcanol. 37, 183 (1973). 